\title{
SOME ORTHOTROPIC MECHANICAL PROPERTIES OF SESSILE OAK (QUERCUS PETREA) AS INFLUENCED BY MOISTURE CONTENT
}

\author{
Ergün GÜNTEKİN1*, Tuğba YILMAZ AYDIN¹, Peter NIEMZ² \\ ${ }^{1}$ Süleyman Demirel Üniversitesi, Orman Fakültesi, Orman Endüstri Mühendisliği Bölümü, Isparta/TÜRKIYE, \\ ergunguntekin@sdu.edu.tr \\ ${ }^{2}$ Institute for Building Materials, Wood Physics Group, ETH Zürich, Switzerland
}

\begin{abstract}
\end{abstract}
In this study, the influence of moisture content on some orthotropic mechanical properties of sessile oak which is one of the most important wood species grown in Turkey and common in the furniture industry have been investigated. The properties studied include Young's modulus, Poisson's ratios and compression strength of oak wood in three anatomical directions. These properties are important input parameters for three dimensional modeling of mechanical behavior in advanced computer programs such as finite elements. The samples which were approximately $20 \times 20 \times 60 \mathrm{~mm}$ in dimensions were conditioned at $20{ }^{\circ} \mathrm{C}$ and 50, 65, 85, $95 \%$ relative humidity conditions for $6-8$ weeks and subjected to compression tests in order to determine elastic and strength properties. Results indicate that properties investigated significantly differ among all anatomical directions. Young's modulus ranged from 10305 to $6984 \mathrm{~N} / \mathrm{mm}^{2}$ in L direction, from 2032 to $1132 \mathrm{~N} / \mathrm{mm}^{2}$ in R direction and from 1208 to 715 in T direction. Compression strength varied between 48.5 and $25.5 \mathrm{~N} / \mathrm{mm}^{2}$ in $\mathrm{L}$ direction, 16.45 and $9.60 \mathrm{MPa}$ in $\mathrm{R}$ direction, and 10.2 and 7.1 in T direction. Poisson's ratios are found to be in between 0.061 and 0.7. Results indicated that all properties of the samples tested were strongly affected by moisture content.

Keywords: sessile oak, orthotropic properties, moisture content

Özet

Bu çalışmada Türkiye'de yetişen önemli ağaç türlerimizden olan ve mobilya sanayisinde yaygın kullanılan sapsız meşe (Quercus petrea) odununun bazı ortotropik mekanik özellikleri üzerine rutubetin etkisi incelenmiştir. Çalışmada kayın odununun lif, radyal ve teğet yönlerdeki Young modülü, Poisson oranları ve basma dirençleri incelenmiştir. Bu özellikler sonlu elemanlar gibi üç boyutlu mekanik davranışın analizinde kullanılan nümerik yöntemleri için önemli parametrelerdir. Yaklaşık 20x20x60 mm ölçülerde hazırlanan deney örnekleri $20{ }^{\circ} \mathrm{C}$ sabit sıcaklık ve \%50, 65, 85, 95 bağıl nem şartlarında 6-8 hafta bekletilerek basma testlerine maruz birakılmış ve elastik ve direnç özellikleri ortaya konulmuştur. Çalışma sonuçları incelenen özelliklerin anatomik yönlerde önemli ölçüde farklı olduğunu ortaya koymuştur. Örneklerin ortalama elastikiyet modülleri L yönünde 10305 ile $6984 \mathrm{~N} / \mathrm{mm}^{2}$, R yönünde 2032 ile 1132 $\mathrm{N} / \mathrm{mm}^{2}$, T yönünde ise 1208 ile $715 \mathrm{~N} / \mathrm{mm}^{2}$ arasında değişmektedir. Direnç değerleri; L yönünde 48.5 ile $25.5 \mathrm{~N} / \mathrm{mm}^{2}$, $\mathrm{R}$ yönünde 16.45 ile $9.6 \mathrm{~N} / \mathrm{mm}^{2}$, T yönünde ise 10.2 ile $7.1 \mathrm{~N} / \mathrm{mm}^{2}$ arasında değişmektedir. Poisson oranları ise 0.061 ile 0.7 arasında değişmektedir. Çalışma sonuçları test edilen özellikleri önemli ölçüde rutubetten etkilendiğini göstermektedir.

Anahtar kelimeler: Sapsız meşe, ortotropik mekanik davranış, rutubet 


\section{INTRODUCTION}

Wood always in equilibrium with the surrounding environment in use, and most of its properties are considerably affected by moisture content (MC). Most of its mechanical properties will vary inversely with the moisture below fiber saturation point (Panshin and de Zeeuw 1980). Above fiber saturation point the mechanical properties are not effected by changes in MC. Some strength properties may decrease again after reaching a maximum value in between $\mathrm{MC}$ of $0-10 \%$ (Ross, 2010). Strength properties are more sensitive to MC than stiffness properties and static properties are more sensitive than dynamic properties (Dinwoodie 2000).

Although the influence of MC on the mechanical behavior of wood in the longitudinal (L) direction is relatively well known, studies on the behavior in the perpendicular directions $(\mathrm{R}$ and $\mathrm{T}$ ) are limited (Gerhards 1982). The interest on the moisture dependent orthotropic behavior is not new, but only few studies investigated moisture dependent elastic properties of wood in the $\mathrm{R}$ and $\mathrm{T}$ directions (McBurney and Drow 1962, Hering et al. 2012a, Hering et al. 2012b, Ozyhar et al. 2013a, Ozyhar et al. 2013b, Güntekin et al. 2016). Furthermore, moisturedependent wood strength in the $\mathrm{R}$ and $\mathrm{T}$ directions, remain unknown for most wood species. While selected moisture effected elastic properties for some wood species can be found in (Ross 2010), in general, only selected properties were tested for a given property-MC combination in most investigations. As a consequence, complete datasets including the moisture-dependent orthotropic behavior are missing for most wood species.

Elastic and strength properties based on the three dimensional approach are essential input parameters required for advanced computational models used in engineering analysis. The mechanical investigation regarding Turkish wood species generally concerned with behavior at

$$
E_{i}=\frac{\Delta \sigma_{i}}{\Delta \varepsilon_{i}}=\frac{\sigma_{i, 2}-\sigma_{i, 1}}{\varepsilon_{i, 2}-\varepsilon_{i, 1}} \quad i \in R, L, T
$$

constant $\mathrm{MC}$ of $12 \%$. The properties investigated for the study comprise the Young's modulus, Poisson's ratios, and compression strengths in principal directions.

\section{MATERIALS AND METHODS}

Small clear wood samples which were $20 \mathrm{x}$ $20 \times 60 \mathrm{~mm}$ in dimensions prepared from Sessile oak (Quercus petrea) logs harvested from Devrek Forest District in Turkey. Before testing, compression specimens were randomly divided into four groups and conditioned in climatic chambers at 50, 65, 85 and $95 \%$ relative humidity $(\mathrm{RH})$ at a temperature of $20{ }^{\circ} \mathrm{C}$. After the specimen had reached equilibrium $\mathrm{MC}$, uniaxial compression tests were carried out using a Zwick 100 universal testing machine. All tests were performed at standard climatic conditions $(65 \%$ $\mathrm{RH}$ and $20^{\circ} \mathrm{C}$ ). To minimize the influence of the MC change, specimens were tested immediately after removal from the climatic chamber. Wood MC was determined by the oven-drying method. The feed rate was defined in such a way that the failure of the specimen should be reached in 90 $( \pm 30)$ s. The strains were evaluated using the digital image correlation (DIC) technique. A high contrast random dot texture was sprayed on the surface of the specimen with air-brush to ensure the contrast needed for the evaluation of the displacements. Pictures were taken with a frequency of $4 \mathrm{~Hz}$ of the cross-sectional surface area of the specimen during testing (Figure 1). By means of the mapping software (VIC 2D, Correlated Solution), the surface strains were calculated from the displacements that occurred during deformation. A more detailed description of the strain computation by the DIC technique is given in Keunecke et al. (2008). The stressstrain curves obtained were used in order to evaluate Young's moduli and strength properties of the specimens. The Young's modulus was calculated from the ratio of the stress $\sigma$ to the strain $\varepsilon$ measured in the linear elastic range: 


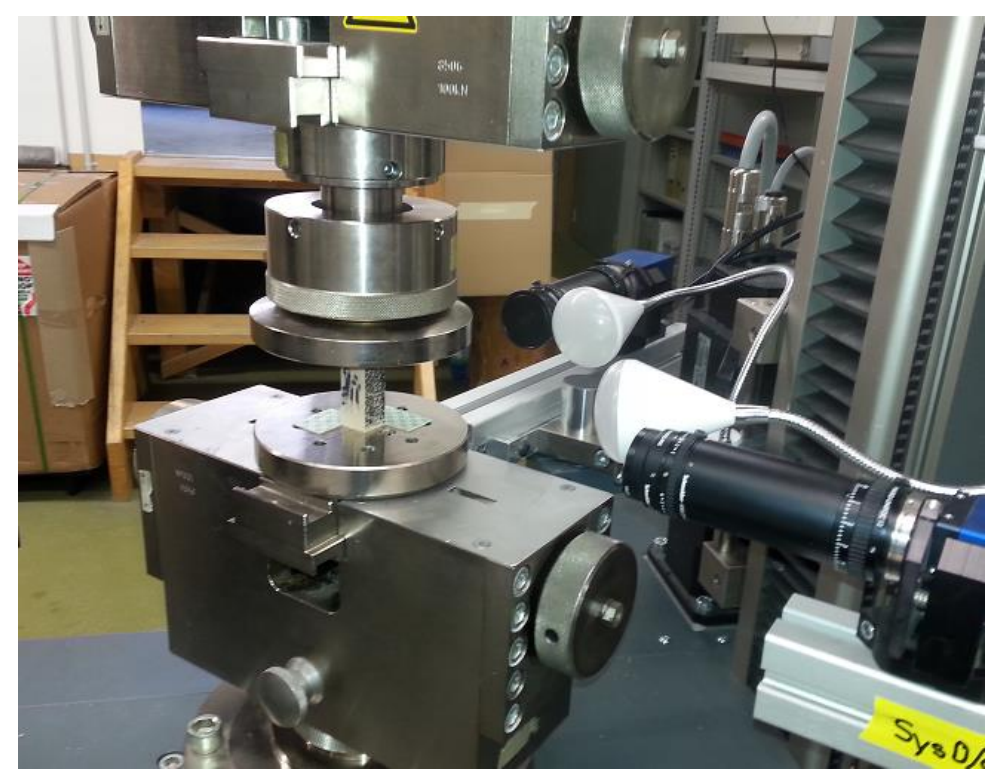

Figure 1. Compression test set up.

The Poisson's ratio $\nu$, defined as

$$
v_{\mathrm{ij}} \quad=-\frac{\varepsilon_{j}}{\varepsilon_{i}}
$$

Where; $\varepsilon_{\mathrm{i}}$ represents the active strain component in the load direction and $\varepsilon_{\mathrm{j}}$ is the passive (lateral) strain component, which was determined in the linear elastic range from the linear regression of the passive-active strain diagram. Since the strength behavior of wood in $\mathrm{R}$ and $\mathrm{T}$ directions is obscure, maximum compression strength was calculated using $0.2 \%$ yield values using following formula.

$\sigma_{U C S}=P_{\max } / A$

Where; $\sigma_{U C S}$ represents yield strength, $P_{\max }$ is the yield load and $A$ is the cross-sectional area of the specimen. Analysis of variance (ANOVA) general linear model procedure was run for data with SAS statistical analysis software to interpret effects of MC on the properties measured of the clear wood samples.

\section{RESULTS AND DISCUSSIONS}

Average values for Young's modulus of the specimens tested are presented in Table 1. There was a good match among the density values in the different MC groups. In comparison to available literature references at similar MC, the $\mathrm{i}, j \in \mathrm{R}, \quad \mathrm{L}, \quad \mathrm{T} \quad$ and $\quad \mathrm{i} \quad \neq \mathrm{j}$

measured density values were comparable. The densities of the investigated oak species grown in Turkey varies in between 0.59 and $0.74 \mathrm{~g} / \mathrm{cm}^{3}$. Coefficient of variation in Young's modulus values ranged from $12 \%$ to $33 \%$ which is acceptable for mechanical properties of wood.

The ratio of Young's modulus in L, R and $\mathrm{T}$ directions was approximately 8.5:1.6:1. According to Bodig and Jayne (1983) the ratio of Young's modulus in principal directions can be as much as 20:1.6:1. The only elastic property available for oak species grown in Turkey is modulus of elasticity in bending (MOE) which varies between $10000-13000 \mathrm{~N} / \mathrm{mm}^{2}$ at $\mathrm{MC}$ of $12 \%$.

In general, Young's modulus in all anatomical directions tended to increase at lower MC as expected (Figure 2). The three Young's moduli values are affected by moisture, but to a different degree. Young's modulus in the direction perpendicular to the grain $(\mathrm{R}, \mathrm{T})$ changes with $\mathrm{MC}$ at lower rates. The changing rates of Young's modulus due to $1 \% \mathrm{MC}$ in $\mathrm{L}, \mathrm{R}$ and $\mathrm{T}$ directions were nearly 5, 4.3 and $4.2 \%$ 
respectively. Similar trend in mechanical properties due to the MC changes in $\mathrm{R}$ and $\mathrm{T}$ directions was reported by Gerhards (1982), Ross (2010), Hering et al. (2012a) and Ozyhar et al. (2013a).

The Poisson's ratios calculated from the compression tests are presented in Table 2. It was found that Poisson's ratio varies from 0.061 in TL plane to 0.7 in RT plane at MC of $12 \%$. The Poisson's ratios calculated for Sessile oak in this study in LT, RL and LR directions are similar for oak species reported by Ross (2010). But, they are different in TR, RT and TL directions. Coefficient of variation in Poisson's ratios ranged from $12 \%$ to $57 \%$. Poisson's ratios in the TL and LR plane showed the highest coefficient of variation. High variability in the Poisson's ratios was also implied by Hering et al. (2012a), Ozyhar et al. (2013a), Jeong et al. (2010), Mizutani and Ando (2015). Poisson's ratios seem to be higher for higher MC values (Figure 3). ANOVA results indicated that the effect of MC on Poisson's ratios is significant for the MC levels tested. Although no profound effects of MC on Poisson's ratios LR, TR, and RT were found in the studies of Drow and McBurney (1954), a slight decrease in Poisson's ratios with increasing $\mathrm{MC}$ was reported by Hering et al. (2012a), and a significant effect of MC on Poisson's ratios was implied by Mizutani and Ando (2015) for wider range of MC (0-177 $\%)$.

Table 1. Young's modulus values $\left(\mathrm{N} / \mathrm{mm}^{2}\right)$ for Sessile oak

\begin{tabular}{|c|c|c|c|c|}
\hline $20^{\circ} \mathrm{C}$, R.H. $(\%)$ & & $\mathrm{E}_{\mathrm{L}}$ & $\mathrm{E}_{\mathrm{R}}$ & $\mathrm{E}_{\mathrm{T}}$ \\
\hline \multirow[t]{5}{*}{50} & Mean & 10305 & 2032 & 1208 \\
\hline & $\operatorname{Cov}(\%)$ & 30 & 21 & 12 \\
\hline & $\mathrm{n}$ & 12 & 12 & 12 \\
\hline & Density $\left(\mathrm{g} / \mathrm{cm}^{3}\right)$ & 0.66 & 0.67 & 0.65 \\
\hline & M.C. $(\%)$ & 12.1 & 11.6 & 11.9 \\
\hline \multirow[t]{5}{*}{65} & Mean & 9845 & 1883 & 1105 \\
\hline & $\operatorname{Cov}(\%)$ & 19 & 32 & 17 \\
\hline & $\mathrm{n}$ & 12 & 12 & 12 \\
\hline & Density $\left(\mathrm{g} / \mathrm{cm}^{3}\right)$ & 0.67 & 0.68 & 0.67 \\
\hline & M.C. $(\%)$ & 12.8 & 12.8 & 12.3 \\
\hline \multirow[t]{5}{*}{85} & Mean & 7850 & 1312 & 852 \\
\hline & $\operatorname{Cov}(\%)$ & 32 & 25 & 32 \\
\hline & $\mathrm{n}$ & 12 & 12 & 12 \\
\hline & Density $\left(\mathrm{g} / \mathrm{cm}^{3}\right)$ & 0.69 & 0.72 & 0.68 \\
\hline & M.C. $(\%)$ & 20.8 & 20.5 & 20.9 \\
\hline \multirow[t]{5}{*}{95} & Mean & 6984 & 1132 & 715 \\
\hline & $\operatorname{Cov}(\%)$ & 33 & 31 & 18 \\
\hline & $\mathrm{n}$ & 12 & 12 & 12 \\
\hline & Density $\left(\mathrm{g} / \mathrm{cm}^{3}\right)$ & 0.71 & 0.75 & 0.69 \\
\hline & M.C. $(\%)$ & 23.3 & 22.6 & 22.1 \\
\hline
\end{tabular}




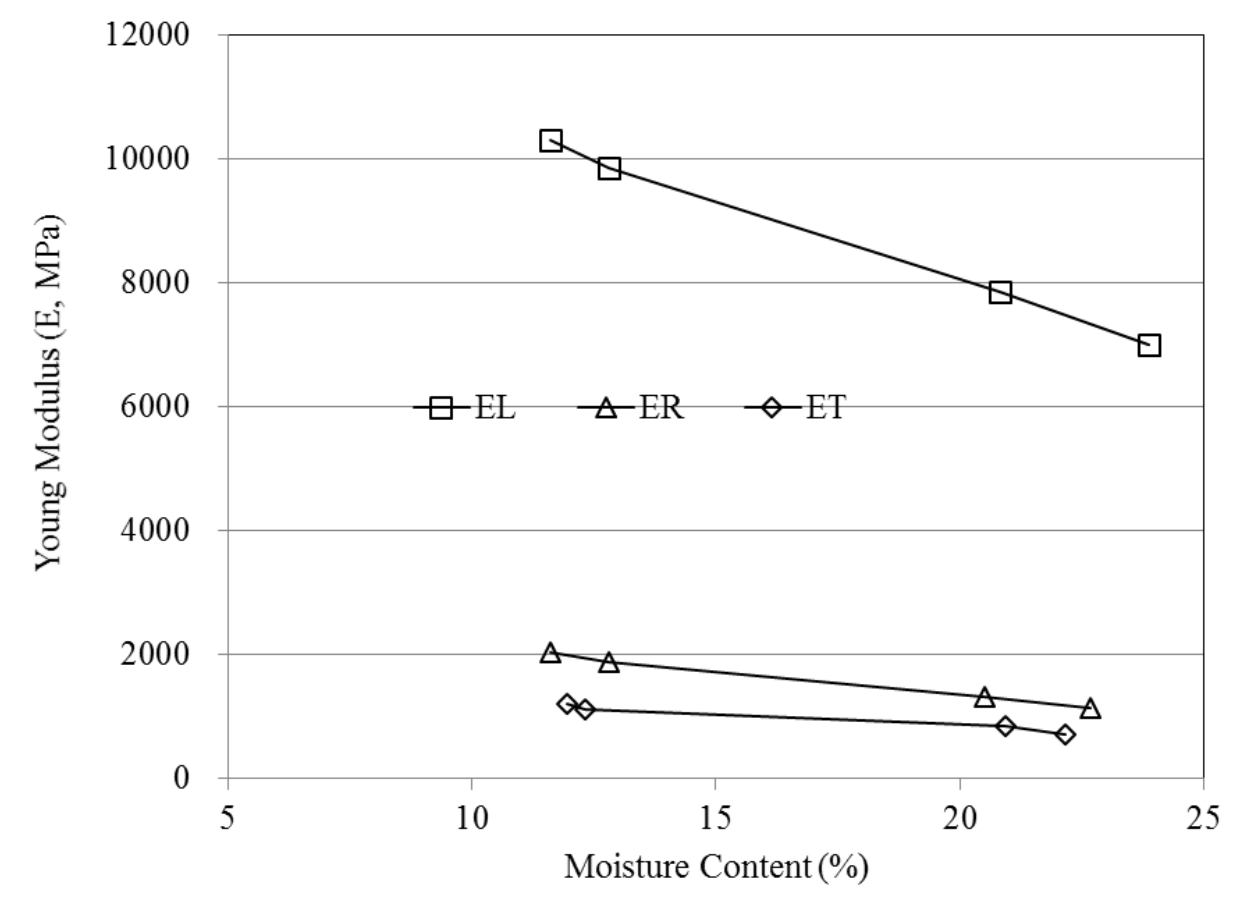

Figure 2. Influence of MC on Young's modulus in three orthotropic directions of sessile oak

Table 2. Poisson ratios for Sessile oak

\begin{tabular}{|c|c|c|c|c|c|c|c|}
\hline R.H. (\%) & & $v_{T L}$ & $v_{R L}$ & $v_{T R}$ & $v_{R T}$ & $v_{L T}$ & $v_{L R}$ \\
\hline \multirow{5}{*}{50} & Mean & 0.061 & 0.082 & 0.41 & 0.7 & 0.42 & 0.36 \\
\hline & $\operatorname{Cov}(\%)$ & 24 & 19 & 12 & 20 & 31 & 28 \\
\hline & $\mathrm{n}$ & 12 & 12 & 12 & 12 & 12 & 12 \\
\hline & Density $\left(\mathrm{g} / \mathrm{cm}^{3}\right)$ & 0.65 & 0.67 & 0.65 & 0.67 & 0.66 & 0.66 \\
\hline & M.C. $(\%)$ & 11.9 & 11.6 & 11.9 & 11.6 & 12.1 & 12.1 \\
\hline \multirow[t]{5}{*}{65} & Mean & 0.069 & 0.103 & 0.73 & 0.86 & 0.53 & 0.42 \\
\hline & $\operatorname{Cov}(\%)$ & 48 & 44 & 16 & 8 & 32 & 34 \\
\hline & $\mathrm{n}$ & 12 & 12 & 12 & 12 & 12 & 12 \\
\hline & Density $\left(\mathrm{g} / \mathrm{cm}^{3}\right)$ & 0.67 & 0.68 & 0.67 & 0.68 & 0.67 & 0.67 \\
\hline & M.C. $(\%)$ & 12.3 & 12.8 & 12.3 & 12.8 & 12.8 & 12.8 \\
\hline \multirow[t]{5}{*}{85} & Mean & 0.08 & 0.11 & 0.79 & 0.93 & 0.68 & 0.59 \\
\hline & $\operatorname{Cov}(\%)$ & 57 & 45 & 39 & 36 & 22 & 21 \\
\hline & $\mathrm{n}$ & 15 & 15 & 15 & 15 & 15 & 15 \\
\hline & Density $\left(\mathrm{g} / \mathrm{cm}^{3}\right)$ & 0.68 & 0.72 & 0.68 & 0.72 & 0.69 & 0.69 \\
\hline & M.C. $(\%)$ & 20.9 & 20.5 & 20.9 & 20.5 & 20.8 & 20.8 \\
\hline \multirow[t]{5}{*}{95} & Mean & 0.083 & 0.118 & 0.86 & 1.0 & 0.83 & 0.62 \\
\hline & $\operatorname{Cov}(\%)$ & 24 & 28 & 24 & 20 & 15 & 18 \\
\hline & $\mathrm{n}$ & 15 & 15 & 15 & 15 & 15 & 15 \\
\hline & Density $\left(\mathrm{g} / \mathrm{cm}^{3}\right)$ & 0.69 & 0.75 & 0.69 & 0.75 & 0.71 & 0.71 \\
\hline & M.C. $(\%)$ & 22.1 & 22.6 & 22.1 & 22.6 & 23.3 & 23.3 \\
\hline
\end{tabular}




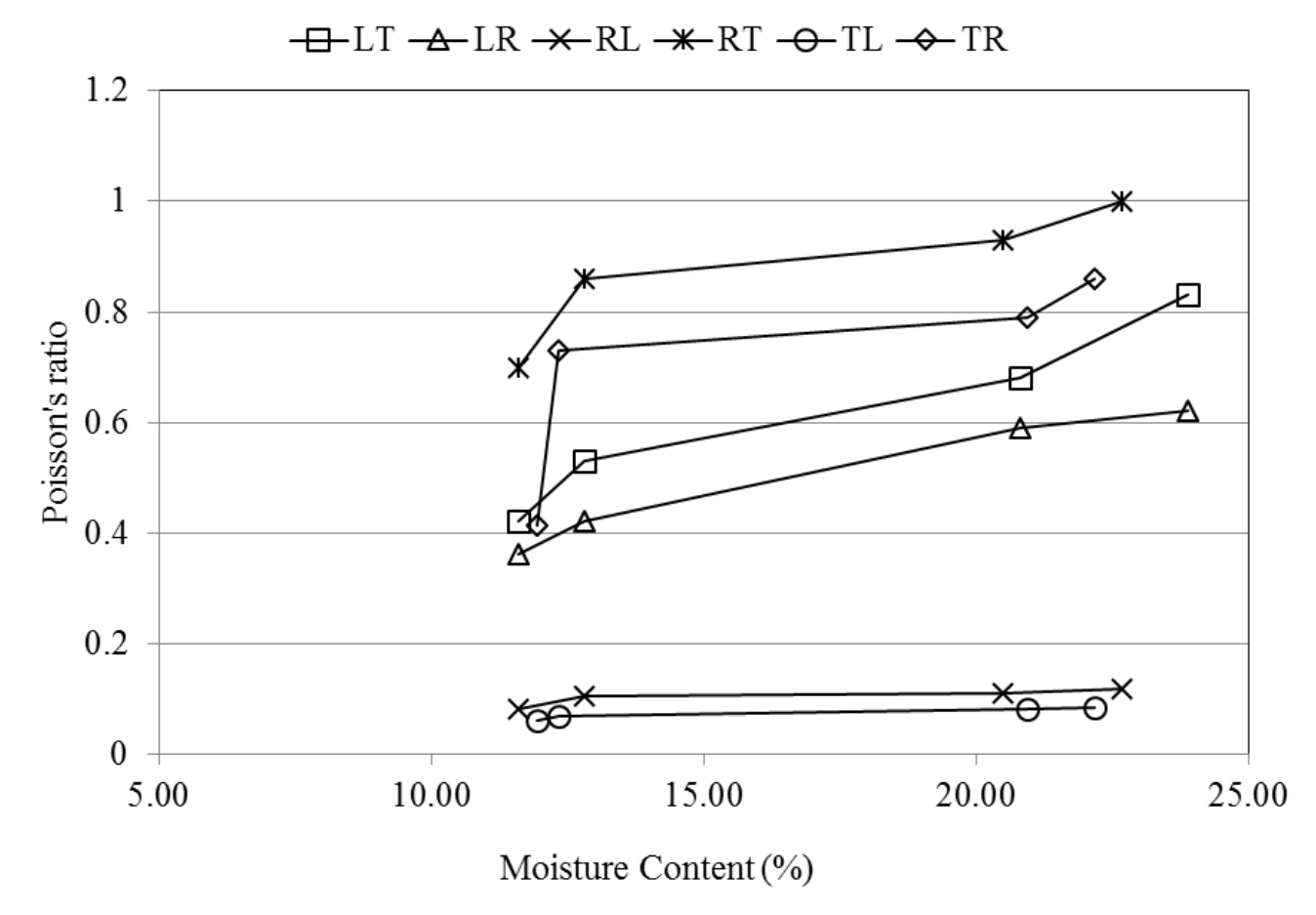

Figure 3. Influence of MC on Poisson's ratio for sessile oak

Average values for compression strength in $\mathrm{L}, \mathrm{R}, \mathrm{T}$ directions calculated in this study are shown in Table 3. The average compression strength of oak species varies from 51 to 75 $\mathrm{N} / \mathrm{mm}^{2}$ (Berkel 1970, Dündar 2002, Keskin 2004, Munoz and Gete 2011, Perçin et al. 2015). Sessile oak used in these tests appears to be somewhat lower in compression strength $\mathrm{L}$ direction than average reported in the literature. The ratio of compression strength in $\mathrm{L}, \mathrm{R}$ and $\mathrm{T}$ directions was approximately $4.8: 1.6: 1$. No data is available for compression strength in perpendicular directions. Figure 4 illustrates the change in CS due to the MC.

\section{CONCLUSIONS}

The results of this study reveal that elastic properties and compression strength in three anatomic directions of Sessile oak are significantly different. The results also indicate that significant influence of MC on both the elastic and strength behavior is clearly visible. The results found in the study affirm the importance of knowing the MC dependency of the mechanical behavior of wood and provide data for numerical simulations taking into account the hygroscopic nature of wood. Results of the study can be utilized in advanced modeling behavior of Sessile oak wood where exposed to structural loads and MC. 
Table 3. Compression strength values for Sessile oak

\begin{tabular}{|c|c|c|c|c|}
\hline R.H. (\%) & & $\mathrm{E}_{\mathrm{L}}$ & $E_{R}$ & $\mathrm{E}_{\mathrm{T}}$ \\
\hline \multirow[t]{5}{*}{50} & Mean & 48.5 & 16.45 & 10.25 \\
\hline & $\operatorname{Cov}(\%)$ & 24.20 & 8.33 & 13.21 \\
\hline & $\mathrm{n}$ & 12 & 12 & 12 \\
\hline & Density $\left(\mathrm{g} / \mathrm{cm}^{3}\right)$ & 0.66 & 0.67 & 0.65 \\
\hline & M.C. $(\%)$ & 12.1 & 11.6 & 11.9 \\
\hline \multirow[t]{5}{*}{65} & Mean & 45.2 & 14.95 & 9.85 \\
\hline & $\operatorname{Cov}(\%)$ & 15.11 & 7.45 & 17.61 \\
\hline & $\mathrm{n}$ & 12 & 12 & 12 \\
\hline & Density $\left(\mathrm{g} / \mathrm{cm}^{3}\right)$ & 0.67 & 0.68 & 0.67 \\
\hline & M.C. $(\%)$ & 12.8 & 12.8 & 12.3 \\
\hline \multirow[t]{5}{*}{85} & Mean & 28.4 & 10.23 & 7.55 \\
\hline & $\operatorname{Cov}(\%)$ & 13.79 & 12.63 & 25.98 \\
\hline & $\mathrm{n}$ & 14 & 15 & 15 \\
\hline & Density $\left(\mathrm{g} / \mathrm{cm}^{3}\right)$ & 0.69 & 0.72 & 0.68 \\
\hline & M.C. $(\%)$ & 20.8 & 20.5 & 20.9 \\
\hline \multirow[t]{5}{*}{95} & Mean & 25.5 & 9.60 & 7.14 \\
\hline & $\operatorname{Cov}(\%)$ & 11.54 & 13.65 & 28.50 \\
\hline & $\mathrm{n}$ & 14 & 15 & 12 \\
\hline & Density $\left(\mathrm{g} / \mathrm{cm}^{3}\right)$ & 0.71 & 0.75 & 0.69 \\
\hline & M.C. $(\%)$ & 23.3 & 22.6 & 22.1 \\
\hline
\end{tabular}

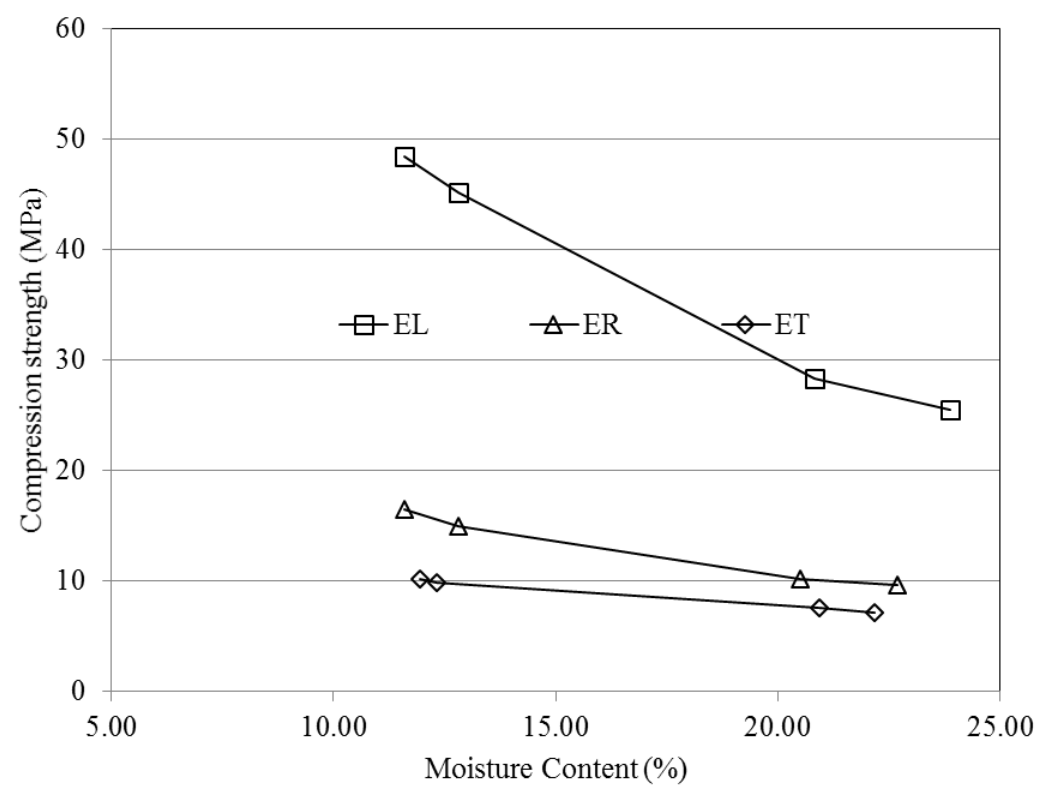

Figure 4. Influence of MC on Compression strength in three orthotropic directions of sessile oak

\section{Acknowledgments}

The data presented here are a part of results obtained through projects sponsored by SDU BAP 3670-D2-2013, TUBITAK 2214/A, and TUBITAK 2219. 


\section{References}

Berkel, A. (1970). Ağaç Malzeme Teknolojisi. İ.Ü. Orman Fakültesi Yayınları, İstanbul.

Bodig, J., Jayne, B. A. (1993). Mechanics of Wood and Wood Composites. Malabar, USA: Krieger Publishing Company, 1993.

Dinwoodie, J.M. (2000). Timber: Its Nature and Behavior. E \& FN Spon, London.

Dündar, T., (2002). Demirköy yöresi 1stranca meşelerinin (Quercus hartwissiana stev.) mekanik özellikleri. İstanbul Üniversitesi Orman Fakültesi Dergisi, 51(2), 159-172.

Gerhards, C.C. (1982). Effect of moisture content and temperature on the mechanical properties of wood: An analysis of immediate effects. Wood and Fiber Science 14(1), 4-36.

Güntekin, E., Yılmaz Aydın, T., Niemz, P. 2016. Some orthotropic elastic properties of Fagus orientalis as influenced by moisture content. Wood Research, 61 (1), 95-104.

Hering, S., Keunecke, D., Niemz, P. (2012a). Moisture-dependent orthotropic elasticity of beech wood. Wood Sci. Technol,.45, 927 - 938.

Hering, S., Saft, S., Resch, E., Niemz, P., Kaliske, M. (2012b). Characterization of moisturedependent plasticity of beech wood and its application to a multi-surface plasticity model. Holsforschung, 66, 373-380.

Jeong, G.Y., Hindman, D.P., Zink-Sharp, A., 2010. Orthotropic properties of loblolly pine (Pinus taeda) strands. J Mater Sci (45), 5820-5830.

Keskin, H., 2004. Sapsız meşe (Quercus petraea liebl.) ve sarıçam (Pinus sylvestris lipsky) kombinasyonu ile üretilmiş lamine ağaç malzemelerin bazı teknolojik özellikleri ve kullanım imkanları. G.Ü. Fen Bilimleri Dergisi, 17(4), 121-13.
Keunecke, D., Hering, S., Niemz, P. (2008). Threedimensional elastic behavior of common yew and Norway spruce. Wood Science Technology, 42, 633-647.

McBurney ,R.S., Drow, J.T. (1962). The Elastic Properties Of Wood: Young's Moduli and Poisson's Ratios of Douglas-fir and Their Relations to Moisture Content. Report No. 1528-D. U.S. Dept. Of Agriculture, Forest Service, Forest Products Laboratory Madison, Wisconsin.

Mizutani, M., Ando, K., 2015. Influence of a wide range of moisture contents on the Poisson's ratio of wood. J Wood Science, (61), 81-85.

Munoz, G.R., Gete, A.R., 2011. Relationships between mechanical properties of oak timber (Quercus robur L.). Holaforschung, 65, 749-755.

Panshin, A.J., de Zeeuw, C. (1980). Textbook of Wood Technology. McGraw-Hill, Inc. New York.

Ozyhar, T., Hering, S., Niemz, P. (2013a). Moisturedependent orthotropic tension compression asymmetry of wood. Holzforschung; 67(4), 395-404.

Ozyhar, T., Hering, S., Niemz, P. (2013b). Viscoelastic characterization of wood: Time dependence of the orthotropic compliance in tension and compression. Journal of Rheology. (57), 699-715.

Perçin, O., Sofuoğlu. S.D., Uzun, O., (2015). Effect of boron impregnation and heat threatment on some mechanical properties of oak (Quercus petrea liebl.) wood. Bioresources, 10(3), 39633978.

Ross, R.J., 2010. Wood Handbook: Wood as an Engineering Material. General Technical Report. FPL-GTR 190, U.S. Department of Agriculture, Forest Service, Forest Products Laboratory, Madison, WI.

Submitted: 06.05.2016

Accepted: 11.06.2016 